\title{
Images Of The West In Urban Indonesia: Muslims Negotiating the Western Path to Modernity
}

\author{
Melanie V. Nertz 1 \\ ${ }^{1}$ Dept. of Cultural and Social Anthropology, Albert-Ludwig-University, Freiburg, Germany. \\ E-mail: melanie.nertz@ethno.uni-freiburg.de
}

\begin{abstract}
Islamic fundamentalism and terrorism is unjustified. In fact, the political change after 1998 and the increasing influence of religion combined with an intensified process of globalization have led to socio-cultural vicissitudes inIndonesia beyond which we can only estimate what future patterns of orientation the population will have. Based on data from informal conversations, interviews and participant observation, it will be argued that, notwithstanding considerable variations, Muslim Indonesians uphold not solely negative but ambivalent images of the West and that in comparison with and opposition to the 'Self' or 'Own' the West is examined as one of many frames of reference by which modernity is negotiated and can be put into practice. Many interlocutors overcame the binary of East and West by envisioning that Indonesia could combine the advantages of both, the Own and the Foreign in order to step into a desirable future.
\end{abstract}

Keyword: West, Urban, Modernity, Occidentalisms

\section{A. INTRODUCTION}

Not only the 9/11 terrorist attacks in the USA and postulates like the "clash of civilizations" but also a general growth of world wide interrelations affecting all aspects of life and society, have contributed to an increased public interest in how the 'West' is perceived by the 'East' and in particular how the 'West' is perceived by 'Islam'. In this context, Indonesia has attracted international attention due to the Bali bombings in 2002, making the country, which has the world's largest Muslim population (and is the largest Muslim-majority democracy), part of the so-called 'axis of evil' overnight. Yet, even though a social development in the direction of conservative interpretations of Islam can be observed, equating Indonesia exclusively with Islamic fundamentalism and terrorism is unjustified. In fact, the political change after 1998 and the increasing influence of religion combined with an intensified process of globalization have led to socio-cultural vicissitudes inIndonesia beyond which we can only estimate what future patterns of orientation the population will have. Thus recently, especially people in the cities, the main loci of globalization, have to renegotiate their social status and cultural identity. They are in need of repositioning the 'Self', a process that goes hand in hand with the constitution of differences and representations of the foreign.

This paper seeks to explore cultural discourses and constructions of the West as the 'Other' or 'Foreign' among contemporary Muslims in Indonesian urban societies (in particular that of Makassar, South Sulawesi and Yogyakarta, Central Java where I did anthropological fieldwork for five and four month. Questions that will be considered in the following are: How do Muslim Indonesians at the present time position themselves vis-á-vis an imagined West? How is this West perceived, experienced, interpreted and understood? How are current imaginations of and attitudes towards the West connected to and articulated in concepts of and performances of modernity and desirable futures? 
In contrast to Western media coverage that constantly reproduces the longstanding dichotomy between Islam and the West and leaves no doubt about Muslim hatred of the West, it is aimed to show the variety of images of the West that exist among Muslim Indonesians in Makassar and Yogyakarta that comprised, for instance, NGO-employees, students and university lecturers, hotel staff, street vendors and Imams and some of them were affiliated with certain Islamic branches, parties or students associations, while others defined themselves as mere 'identity card Muslims' (Muslim KTP).

Based on data from informal conversations, interviews and participant observation, it will be argued that, notwithstanding considerable variations, Muslim Indonesians uphold not solely negative but ambivalent images of the West and that in comparison with and oppositionto the 'Self' or 'Own' the West is examined as one of many frames of reference by which modernity is negotiated and can be put into practice.

\section{B. METHODOLOGY}

Based on data from informal conversations, interviews and participant observation, it will be argued that, notwithstanding considerable variations

In this section argued that, in a qualitative study, primary data collection techniques were observation, in-depth interviews, document study, and the three combined or triangulation. It should be noted that the technique of collecting data by observation, it is worth noting what is observed, when interviewed, to whom will conduct the interview.

\section{RESULT AND DISCUSSION}

\section{Occidentalisms - Good and bad of 'the modern West'}

A part from locating several Wests, namely the US-American West, the European West, the Australian West and the Muslim West, Muslim Indonesians spoke rather undifferentiated

about Westerners and the West and expressed an ambivalent attitudeiv that was best summarized as follows: 'In my opinion there are good and bad things to say about the West' (interview, 23 March 2011).v People cited positive and negative aspects of the West, which was first and foremost considered as a symbol of modernity: 'If you search for the modern world, go to the West, to Europe, to America' (interview, 2 November 2010). The list of shared images and cultural markers associated with 'the modern West' comprised on the positive side: Western discipline, economic strength and wealth, highranking education systems (and therefore clever Western people), advanced technology, good quality products, democracy, liberalism (related to human rights such as religious freedom or gender equality), and individualism (understood as independency and self-reliance of the subject). Rated negatively were: the remembrance of colonialism, secularization or rather the loss of religion, materialism (often considered as the new religion not only of the West but also of Indonesians), individualism (seen as isolation, loneliness, egoism, selfishness and accompanied by social disintegration and anonymity) and again liberalism (equated with 'free sex'vi, indecent female clothing and consume of alcohol and drugs - altogether things that are seen as crucial indicators of moral decadence).

Thus, from experiences in Western countries, several informants, for instance, greatly admired the feeling of security, which was ascribed to the rule of law. Having graduated in Europe, one informant emphasised the harmonious social life over there and told: 'Life is protected by law; 
people may do whatever they want as long as it is in accordance with the law' (interview, 25 October 2010). Another research participant, head of a modernist Islamic boarding school (pesantren) that has international connections, focused on freedom of expression and more precisely gender equality when he firstly explained: 'They [Westerners, M.V.N.] have an opinion and are allowed to say what they think. I could observe that. There was a married couple who discussed everything together' (interview, 2 November 2010).

Furthermore, he remarked that he had been impressed by the religious tolerance shown towards him when he had been fasting in Ramadan: 'Thus, what I also experienced was that people [Westerners, M.V.N.] were very tolerant: at no time when I was fasting, at no time were there any problems. On the campus, for instance, they [Western students, M.V.N.] apologised when they ate lunch' (interview, 2 November 2010). In addition, Muslim Indonesians were generally in favour of Western behavioural characteristics and ideals such as sense of order, punctuality and thirst for knowledge that - in their eyes - were put into practice in exemplary fashion by Westerners (and were seen as cornerstones of the West's progress in terms of education, technology and economics). One research participant who had worked in the tourism sector for years (first as a waiter, later as an operational manager) had observed that guests from the West were always eager to learn. Pointing to the fact that they would read a lot, he concluded that Westerners are studious and inquisitive in contrast to Indonesians: We admire the fact that Westerners spend a lot of time learning. Wherever they are, they will read and read and read. If they go to the bathroom, if they are on a train or in a restaurant, wherever they are, they will always have a book with them, either beside them on the table or at least in their bag. I think this is what we should pattern ourselves on. (Interview, 2 January 2011)

However, some shared negative images of 'the West' and of 'Western modernity' were put forward by Muslim Indonesians in Makassar and Yogyakarta as well. They mentioned what they considered to be the flip side of the coin or a false liberalism that was incompatible with Indonesian culture: Their doctrine is the idea of freedom. They are free. I mean ... they have a free live. Yes, they live unhampered lives, especially when they come [to Makassar, M.V.N.] in couples, man and woman. Excuse me, not all are like that, they usually say: free life, free sex, drinking alcohol ... they [Westerners, M.V.N.] call it freedom, liberty ... free means they can do whatever they want. This is true in their countries. However, if they come to Indonesia, they will have to respect our culture. (Interview, 2 January 2011)

Additionally, the basic characteristic of the Western life-style, namely being materialistic, was seen as another great shortcoming. It had already led to disorientation among Westerners who do not know about the real need of humanity, namely spirituality. According to my researchparticipants this was quite contrary to people in the East and in Indonesia, whose spiritual strength was praised: Society here [Indonesian society, M.V.N.], societies in the East in general, although their basic material needs have to be met, have a strong spiritual orientation in life: spirituality is strong... Looking at the West, how to say, they are disorientated in their lives because they are already rich in terms of material needs. It is beyond question that this leads to discomfort and uneasiness because there is a spiritual dimension, a spiritual need that they [Westerners, M.V.N.] ignore. Yes, it is unfulfilled. Thus, that is not good, there is no balance. (Interview, 11 January 2011)

The above cited perfectly shows the interrelatedness of the constitution of 'Self' and 'Other' and leads to some necessary theoretical considerations regarding Orientalism and Occidentalism. Famously criticized by Edward W. Said in 1978 for being reductionist representations of 'the Orient' in order to serve as instrument of colonial domination,vii Orientalism seemed to precede 
Occidentalism, a term that was only introduced in 1992 by James G. Carrierviii as a synonym for essentialist images of 'the West' (either defined as 'the projected image of the Western world enjoyed by representatives of "the Orient"'ix or - less commonly - understood as a Western projectx). Yet, this does not hold true due to the intersections of both, now and before. Max Deeg therefore enhanced the concepts by adding the supplementary terms auto-orientalism and autooccidenalism. These terms describe the fact that, while constructing the 'Other' we also create an essentialist image of the 'Self'.

When people from the East do so, it is referred to as auto-orientalism, and auto-occidentalism when Westerners do so.

In the case of my Muslim interviewees the mechanism of auto-orientalism was of two kinds. Where the West was regarded as a shining example, auto-orientalism painted an unfavourable picture of the 'Self', Indonesian government and society. There was widespread negativity - negative self perception and descriptions - in the accounts of the interlocutors, signifying a discontent with current cultural, social and political conditions in Indonesia. Participants were particularly condemning corruption, which is often used as an argument that Indonesia is not yet ready for democracy. This self-criticism was frequently seen in the context of the religious identity of the interviewees, as, for instance, a Muslim lecturer at an Islamic and a Christian university stated: "Islamic values can be found over there [in the West] but not here [in Indonesia]. Although in the West they do not say they are Muslims, I recognized that they put Islamic values to use.

On the contrary, in Islamic countries, including here [Indonesia] all people say: 'I am Muslim', but I realized that they are not because they do not promote Islamic values." (Interview, 11 January 2011). Referring to negative aspects of the West was accompanied by constructions of the 'Self' that were mystifying. Accusing the West of being immoral and lacking spiritual guidance, simultaneously Indonesia or the East was 'equated with moral values and wisdom' (interview, 17 February 2011), although in other contexts informants were worried about the fact that Indonesian youth especially was imitating liberal Western life-style. Thus, working in the tourism sector of Makassar for years (first as a waiter and more recently employed as the operational manager of a medium-sized, family-run hotel), one informant reported the following: I observed that when Westerners come they usually like beer. Once I worked as waiter in a café... they ordered a lot of beer. Those who come to this café are not only Western tourists, our people [people from Makassar, M.V.N.] do so as well and are probably influenced by them. Shameless social intercourse has already been adopted from the West. It is extraordinary how shameless social intercourse has already entered Indonesian society. (Interview, 2 January 2011)

With respect to her peers, one female employee of a non-governmental organisation in Yogyakarta also pointed out the increasingly pro-Western attitudes of young Indonesian women in terms of fashion: When you look at fashion, for example, [young, M.V.N.] people in Indonesia know quite quickly about fashion in Paris. When hot pants became the latest trend five years ago, you could not see women wearing them in public in Yogya [Yogyakarta, M.V.N.], but now [you can, M.V.N.]. That means with Western influence you now see a lot [of hot pants on the streets, M.V.N.]. (Interview, 18 September 2010).And last but not least, a member of the Islamic Students Association (Himpunan Mahasiswa Islam, HMI) in Yogyakarta remarked the already destructive impact that Western materialism had taken on Indonesian society: Slametan are vanishing, [because] we are already pragmatic [in the sense of materialistic], consumerism has grasped us [in Indonesia], that is the influence from the West, culture is changing very much, Ramadan also. When this major religious holiday comes, you have to buy new clothes [now]. (Interview, 23 March 2011) 


\section{Pathways to Alternative Modernities - Modifying the Western Draft by Filtering}

Does modernisation have to mean Westernizing Indonesia? xiv As shown above, informants of mine for the most part had clear ideas of 'the West' and its conditions of modernity. Judging some aspects positively and others negatively, revealed that Muslim Indonesians were notcompletely convinced of what the West provides as a model of a modern nation and society.Thus, being aware of what in their eyes are the pros and cons of Western modernity andfacing Western inflows into their own society resulted in a so-called practice of 'filtering'. More precisely, this meant identifying good and bad about Western life-style, values and concepts and filtering out what was considered unsuitable for Indonesian culture and Muslim religious understandings:Everyone has certain characteristics: one of them is culture. We havealso special characteristics due to our culture. Thus, we should have a filter in order that we do not adopt things that are not appropriate with our culture, yes? So, there is a filter, [and] what fits will be adopted. (Interview, 18 February 2011)

Interestingly, the practice of filtering was as valid for global or foreign influences from theWest as for inflows from the 'Islamic East', but that is another matter.However, dealing with the process of globalisation, and especially with circulating ideas and images of 'the West', was not just a matter of sorting out the negative things. Once they were clear about this, people turned out to be busy learning how to incorporate what were acknowledged as positive examples or useful knowledge from the West in terms of modernisation. Concerning education, for instance, lively discussions were, and still are, held in Muslim academic circles on how to benefit from Western science. There was no doubt about the need to learn from the West in terms of scientific culture. Yet, how to do so was a matter of debate. Muslim intellectuals and students were divided over this issue. Some thought of an explicit model of how to create and guarantee a 'synergy of religion and sciences' (interview, 25 January 2011), while others were in favour of the immediate introduction of Western sciences: Knowledge cannot be changed, whether it is a communist, an atheist, a religious person, someone from the West or someone from the East who discovers it. It is not necessary to Islamise knowledge. [...] We can adopt [Western, M.V.N.] knowledge immediately. What is global is [Western, M.V.N.] knowledge and methodology, these are very beneficial. (Interview, 4 January 2011)

The admiration for Western methodological strength has even gone so far as to set a new trend. Studying Islamic sciences has thus recently shifted from universities in the Middle East to institutions in the West:The right methods to do research, the West has an advantage in this case. [...] Students of Islamic sciences are sent over there. [...] In the Middle East they do not know enough about the right methodology. How to read the holy texts like the Quran, you have to use the right methods; Westerners know how to do it. (Interview, 4 January 2011)

Anyway, it was widely stressed that sciences generated in the West lacked the guidance of moral values to ensure an ethically responsible application - the latter being a task Islam could perform. The final aim was often to modernise by 'becoming more Western than the West' (interview, 25 March 2011), as one member of the Muhammadiyah Students' Association (Ikatan Mahasiswa Muhammadiyah, IMM) in Yogyakarta emphasised. Acquiring secular Western sciences and combining them with respect for Islamic norms would advance the East, in particular Indonesia, to a leading position. In terms of consumerism, practice was much less complex. Despite the danger of material hedonism, spending the weekends in shopping malls and eating at Pizza Hut, Kentucky Fried Chicken or MacDonald's were popular leisure activities among middle- and upperclass Muslim Indonesians in Makassar and Yogyakarta. Being aware of their Western origins, some informants loved to go to these fast-food chains because it is modern, it is its modernity; 
eating in the Western Kentucky means being modern' (interview, 2 November 2010), as well as showing one can afford it. Others said that they just liked the food.

However, none of them had any doubts about whether or not the food was in conformity with Islamic food rules and purity requirements due to the halal labelxx from the Council of Indonesian Ulama (Majelis Ulama Indonesia, MUI).

\section{CONCLUSION}

Dealing with Occidentalism or rather Occidentalisms in contemporary Indonesia, it is striking that perceptions and images of the West did not differ significantly when comparing the selected research sites, Makassar and Yogyakarta. Something that can be ascribed to thesimilar sources from where the informants derive their knowledge of the West: first andforemost from the media, but also from contacts with foreign tourists and/or from travelling or staying abroad or from working relations with Westerners. What was revealed is a common tendency towards the ambivalence and ambiguity for which the West stands in the eyes of the research participants (apart from a few who looked on the West solely negatively and were only mentioned in passing in this paper).

The West is seen as a shining example on the one hand and is considered a source of danger on the other. This conflicting attitude towards the West is most obvious with regard to moral orientations, or rather the ideals of social behaviour. It manifests it self when the West is labelled both 'indecent' with respect to sexual liberalism and 'more Islamic' in terms of respecting human rights. Efforts to put into practice what is considered favourable concerning the West finally result in more or less elaborate modifications of Western life-style or concepts and demonstrate the important role that the active individual plays. Moreover, it is now clear that othering concurrently leads to definition of not one but various Selves and does not necessarily have to result in cultural dissociation: there is also the possibility of cultural appropriation. People create their own paths to an alternative modernity out of a pool of possible references, one of which is especially the West.

The process of negotiation shows that, despite the presence of negative opinions of the West, the majority of Muslim Indonesians in my research sites are not engaged by a general antagonism towards the West. They do not oppose everything that comes from the West but refer to it as example of modernity, though not its sole and undisputed model. What is remarkably is that in their evaluations many interlocutors overcame the binary of East and West by envisioning that Indonesia could combine the advantages of both, the Own and the Foreign in order to step into a desirable future. 


\section{References}

Carrier, J. G. (1992), 'Occidentalism. The world turned upside-down', American Ethnologist 19(2), pp. 195-212.

Deeg, Max (2003), 'Wer eine kennt, kennt keine... - Zur Notwendigkeit der Religionsgeschichte', in Religion im Spiegelkabinett. Asiatische Religionsgeschichte im Spannungsfeld zwischen Orientalismus und Okzidentalismus, ed. Peter Schalk (Uppsala: Uppsala University Press), p. 31.

E. W. Said, (1978), Orientalism. New York: Pantheon Books.

http://www.thejakartapost.com/news/2010/07/08/should-we-gowest- study-islam.html).

Pye, Michael (2003), 'Overcoming Westernism: The end of Orientalism and Occidentalism', in Religion im Spiegelkabinett. Asiatische Religionsgeschichte im Spannungsfeld zwischen Orientalismus und Okzidentalismus, ed. Peter Schalk (Uppsala: Uppsala University Press).

Samuel P. Huntington. (1996). The clash of civilizations and the remaking of world order. New York: Simon \& Schuster. 